\title{
ÁTLÁTSZÓ PMMA MIKROMEGMUNKÁLÁSA FEMTOSZEKUNDUMOS LÉZERREL
}

\section{MICROPROCESSING OF TRANSPARENT PMMA WITH FEMTOSECOND LASER}

\author{
Juhász Gergely ${ }^{1,2^{*}}$ \\ 1 Innovatív Jármüvek és Anyagok Tanszék, GAMF Műszaki és Informatikai Kar, Neumann János Egyetem, \\ Magyarország \\ ²Bay Zoltán Alkalmazott Kutatási Közhasznú Nonprofit Kft., Ipari Anyagtechnológiai Osztály, Magyarország \\ https://doi.org/10.47833/2021.1.ENG.001
}

\section{Kulcsszavak: \\ lézer \\ mikromegmunkálás \\ pmma \\ femtoszedkundumos lézer}

\section{Keywords: \\ laser \\ micromachining \\ pmma \\ femtosecond laser}

\section{Cikktörténet:}

Beérkezett 2021. március 10.

Átdolgozva 2021. április 5.

Elfogadva 2021. április 15.

\begin{abstract}
Összefoglalás
A nagyon rövid impulzus idejü lézerek technológiai fejlödésével a munkadarabok lézersugárral való mikromegmunkálásának lehetősége is egyre jobban tökéletesedik. Ennek indoka, hogy a nagyon rövid impulzus idejü lézersugárral megmunkált darab hevülése nem olyan mértékben történik, mint a hosszabb impulzus idejü vagy a folyamatos üzemü lézerek esetében és emiatt nem képződik olyan mértékben olvadék. $A$ femtoszekundumos lézer továbbá rendelkezik egy másik előnnyel is, ami pedig az, hogy olyan anyag is megmunkálható ezzel a lézersugárral, amelyet hullámhosszából adódóan nem lenne képes. A cikk femtoszekundumos lézerrel történő mikromegmunkálást mutat be átlátszó PMMA alapanyagon.
\end{abstract}

Abstract
With the technological development of ultrashort pulse lasers,
the possibility of micromachining with a laser beam is also
becoming more and more perfect. This is because a piece
machined with an ultrashort pulse laser beam is not heated to the
same extent as longer pulse time or continuous wave lasers and
therefore does not form a melt to such an extent. The
femtosecond laser beam also has another advantage, which is
that a material that cannot be machined due to beam wavelength
can be machined with this laser beam. The article presents
micromachining with a femtosecond laser on a transparent
PMMA substrate.

\section{Bevezetés}

A lézersugaras mikromegmunkálás már régóta megjelent a szakirodalomban, mint megmunkálási technika. A technológia fejlődésével egyre rövidebb impulzusidejü lézerek jelennek meg a piacon, amelyek teljesen új alkalmazási lehetőséget rejtenek magukban. Ilyen alkalmazási területek például a méréstechnika, a nagy pontosságú megmunkálások, a felületkezelések és a mikro-, illetve nano strukturálások. A femtoszekundumos lézerek megjelenésével a mikromegmunkálások minősége nagyságrendekkel javult a hosszabb impulzus idejü lézerekhez

\footnotetext{
* Kapcsolattartó Juhász Gergely. Tel.: +36 706684835

E-mail cím: juhasz.gergely@gamf.uni-neumann.hu
} 
képest. Ez lehetővé tette például a mikro, illetve nano méretü orvosi vagy elektronikus eszközök hatékony és gazdaságos gyártását [1].

Egy ilyen termék például a „Lab on a chip” (LOC), ami olyan eszköz, amely egy vagy több laboratóriumi funkciót egyetlen integrált áramkörbe integrál, mindössze egyetlen millimétertöl néhány négyzetcentiméterig terjedően. A LOC rendkívül kicsi folyadékmennyiséget képes kezelni, legfeljebb pico-liter nagyságrendig (1. ábra) [5].

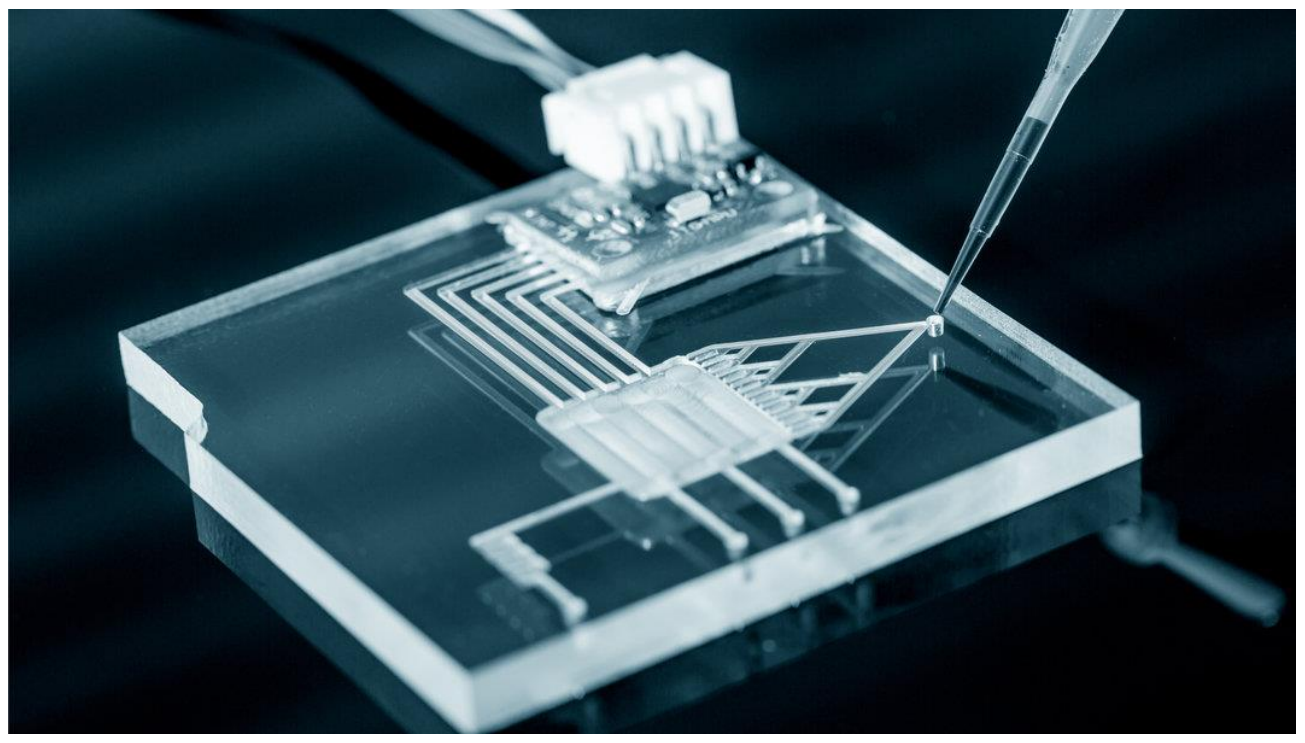

1. ábra. "Lab on a Chip" [2]

Egy ilyen termék elkészítésének rengeteg technológiai kihívása lehet, amelynek egy nagyon rövid impulzus idejü lézer eleget tehet.

\section{Rövid impulzus idejü lézerek}

A világban már régóta jelen vannak az impulzuslézerek. Ahogy a technológia és a mögötte lévő tudomány fejlődött megjelentek a nagyon rövid impulzus idejü lézerberendezések. Az ultrarövid impulzus idejü lézerberendezésekhez tartoznak azok az impulzuslézerek, amelyeknek impulzusidejük rövidebb, mint néhány tíz pikoszekundum (ps). Ilyen berendezések például a pikoszekundumos-, femtoszekundumos- és attoszekundumos lézerek [3, 4].

Az ultrarövid impulzus idejű lézereknek alkalmazása két tulajdonsága miatt különleges: egyrészt a nagyon rövid időtartamukból adódóan, másrészt az impulzusokhoz kapcsolódó hatalmas elektromos és mágneses mezők miatt. Ezért teljesen más fizikai jelenségek játszódnak le, mint a folyamatos üzemü lézerek esetén létrejövő anyag és lézersugár kölcsönhatások során [3].

Ilyen fizikai jelenség például, hogy az ilyen lézersugaras megmunkálásokat hideg megmunkálásnak is megnevezi a szakirodalom. Ez a megmunkálás során keletkező kicsi hőérintett zóna következménye. Egy másik jelenség a nagyon rövid impulzus lézerek esetén a nem lineáris abszorpció, másnéven multifoton abszorpció. Ez a jelenség lehetővé teszi olyan anyagok megmunkálását is, amelyeken egyébként a lézersugár csak keresztül haladna. Ez természetesen nem igaz, mivel minden esetben három dolog történik egy anyag lézersugárral való besugárzása esetén. Az anyagban elnyelödik, vissza reflektálódik, és keresztül halad a lézersugár különböző mértékben. Ez minden esetben jelen van, de például szilárdtest lézer esetén (amelynek hullámhossza a közeli infravörös tartományban van) a lézersugár nagy százalékban keresztül halad minden olyan tárgyon, amely átlátszó az ember számára. Persze erre is van kivétel, mivel készítenek olyan átlátszó terméket, amely nagy százalékban elnyeli az infravörös tartományban lévő hullámokat. llyenek például azok a szemüvegek vagy ablakok, amelyeket a sugárvédelem céljából alkalmaznak szilárdtest lézerek esetében [3, 4]. 


\subsection{Hideg megmunkálás lézersugárral}

Ha összehasonlítjuk a nanoszekundumos (ns) és annál hosszabb impulzus idejü lézerberendezések által megmunkált darabokat egy ultrarövid idejü lézerberendezéssel megmunkálthoz képest, akkor látható az egyértelmű különbség (2. ábra).
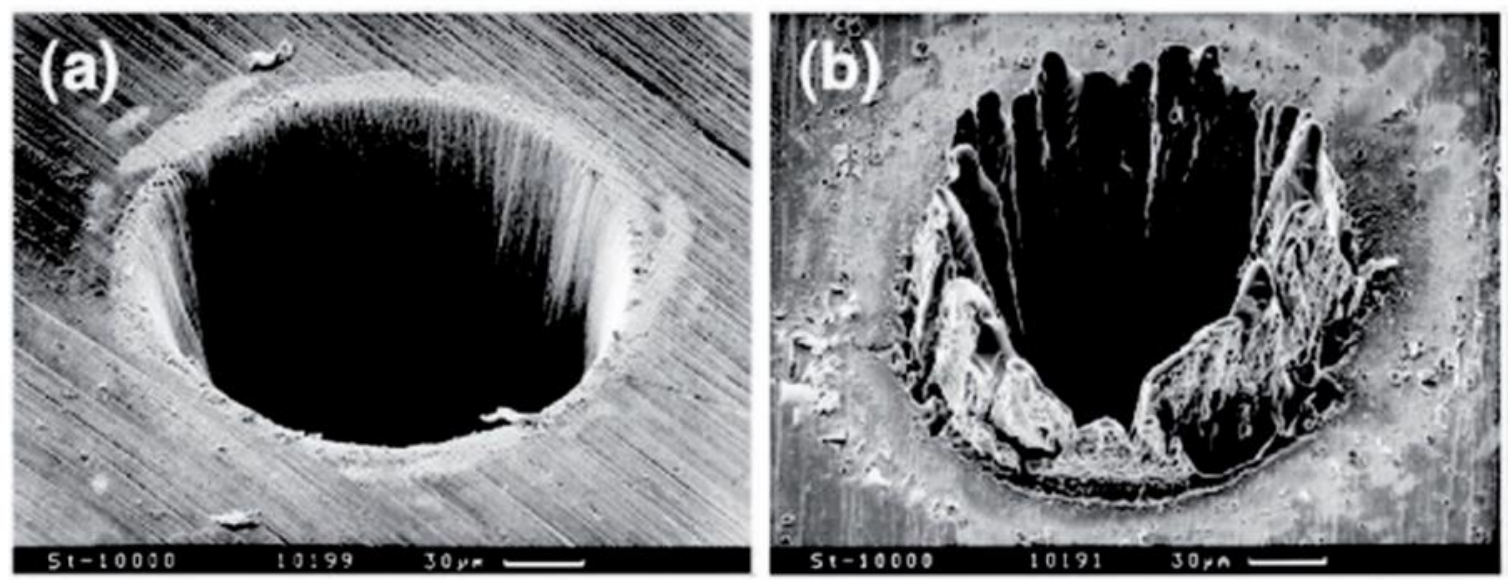

2. ábra. Pásztázó elektron mikroszkópi felvétel egy a) ultrarövid impulzus idejü lézerrel való megmunkálásról és b) egy hosszabb impulzus idejü berendezéssel készült megmunkálásról [3]

Az ultrarövid impulzus idejü lézerberendezés esetén látható, hogy kicsi a hőérintett zóna, amely belátható, hogy pontosabb megmunkáláshoz vezet. Ez a jellemző a gyors energia bevitelnek köszönhető. Egy anyagban az elektronoknak néhány száz fs-tól néhány ps-ig tartó idő szükséges ahhoz, hogy az elektronok ismét termikus egyensúlyba álljanak vissza ultragyors impulzus idejü lézersugárzás esetén. Másrészröl az elektronoknak 1-100 ps időre van szükségük arra, hogy az energiájukat átadják az anyag fonon-alrendszerének. Ez az idő az anyag elektron-fonon kötési erejétöl is függ. Ha az elektronok az energiájukat nem képesek átadni a kristályrácsnak, akkor nem történik hőmérséklet növekedés a kristályrácsban, tehát a tömbi anyagban. Ez az idő sokkal hosszabb, mint az, hogy az elektronok elérjék a termikus egyensúlyukat. Tehát a nagyon rövid impulzusok csak az elektronokat melegítik, létrehozva egy nagyon forró elektron felhőt, amely messze nincs termikus egyensúlyban a kristályráccsal, így nagyon különböznek a hőmérsékleteik. Következésképpen a lézersugár által besugárzott energiának csak egy nagyon kis része adódik át hőként a tömbi anyagnak. A nem termikus megmunkálásból pedig adódik a nagy pontosságú mikromegmunkálás lehetősége [3].

Annak ellenére, hogy a nagyon rövid impulzus idejü lézersugár impulzusok elsődlegesen hideg megmunkálásnak vannak titulálva, attól még fejlődik hő. Azonban ilyen impulzus gyorsaságnál a hőérintett zóna fejlődése el van nyomva a nagyon gyors impulzus idő végett. Viszont, ha a rövid impulzusokat nagy ismétlési rátával juttatjuk az anyagba, akkor már nem lehet a hőérintett zóna keletkezésétől eltekinteni [3].

\subsection{Multifoton-anyag kölcsönhatás}

Az ultrarövid impulzus idejü lézerek erős elnyelödést tudnak kiváltani olyan anyagokban is, amelyeken egyébként a hullámhosszukból adódóan csak keresztül haladnának. A 3. ábra bemutatja egy foton abszorpcióját és egy multifoton elnyelődés folyamatát [3]. 


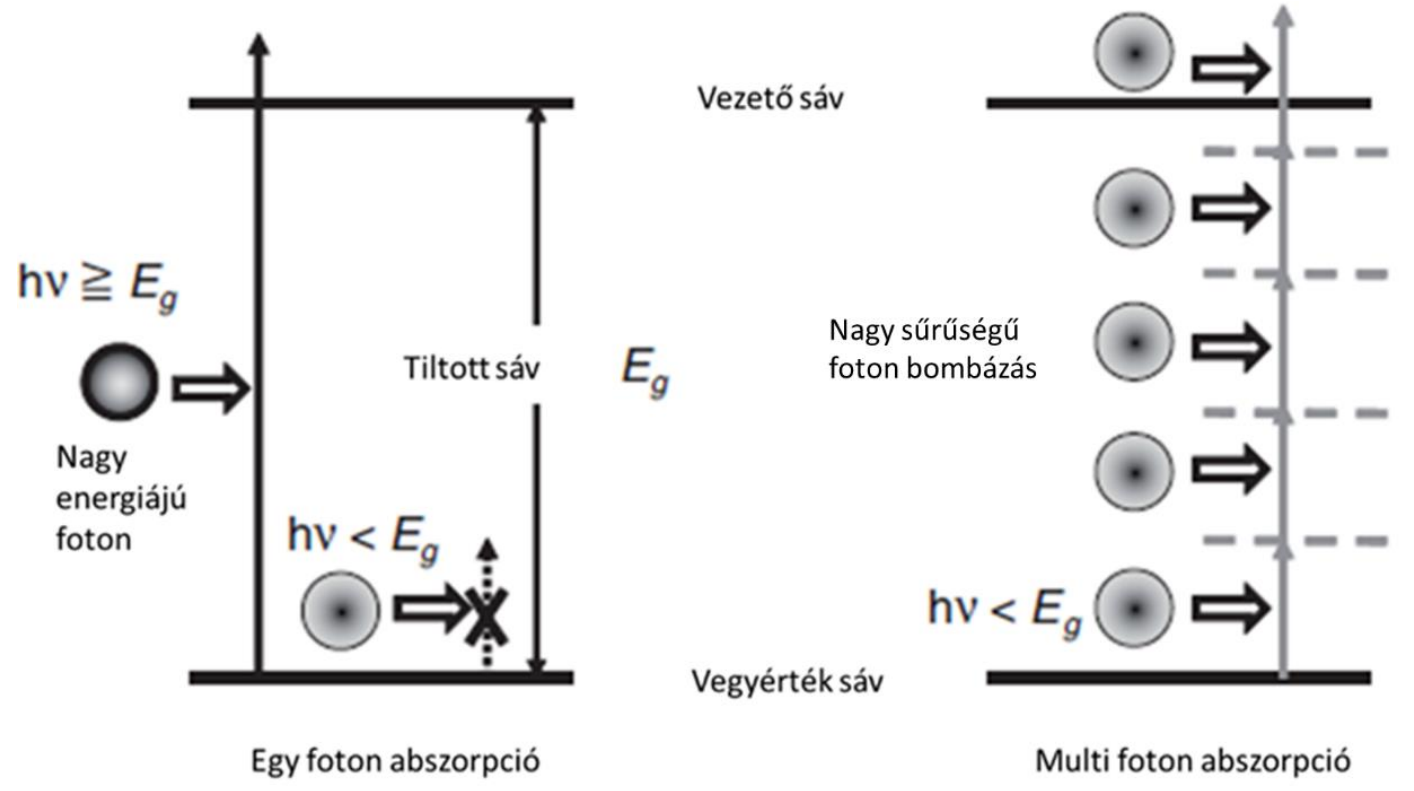

3. ábra. Elektrongerjesztés egy anyagban egy foton (bal) és több foton által (jobb) [3]

Az egyszerü abszorpció esetén lineáris egy foton elnyelődésről beszélünk. Ebben az esetben, amikor a fény (amelynek foton energiája meghaladja az anyag tiltott sávjának energia szintjét) elnyelődik az anyagban (pl. félvezető), akkor egy darab foton megnöveli az elektron energiaszintjét a vegyértéksáv energiaszintjétől a vezetési sáv energia szintjére. Amikor viszont a fénynek a foton energiája kisebb, mint az anyagra jellemző tiltott sáv energiaszintje, akkor az elektronokat nem tudja gerjeszteni. Azonban, amikor nagyon nagy sürüségü foton tömeg (más szóval nagyon magas intenzitású fény) hatol az anyagba, akkor egy elektron gerjeszthető több foton segítségével még akkor is, ha az energia tartalmuk kevesebb, mint a tiltott sáv energiaszintje. Egy félvezető esetében a tiltott sáv energiaszinten nem lehet elektron [3].

Egy nagyon rövid impulzus idejü lézer tud multifoton-anyag kölcsönhatást elöidézni, mivel nagyon magas csúcsteljesítményü, így nagy teljesítménysürüségü lézersugarat tud létrehozni. Ez lehetővé teszi olyan anyagok megmunkálását, amelyet egyébként nem lenne képes. Mivel a multifoton-elektron kölcsönhatásból adódó megmunkálás lehetősége csak akkor lehetséges, ha elég nagy a teljesítmény sürüség, belátható, hogy a megmunkálás területe függ a kellő teljesítménysürüség helyzetétől, amelyet a fókuszálás változtatásával lehet manipulálni (4. ábra) [3]. 


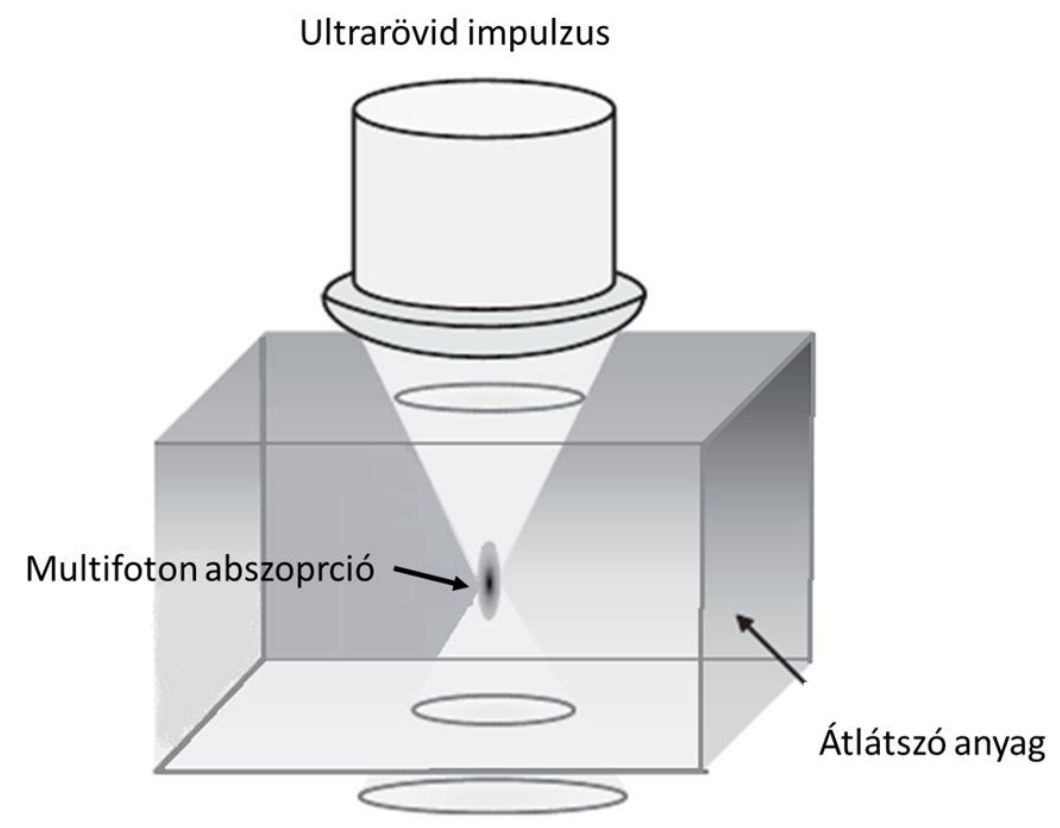

4. ábra. Sematikus ábra a multifoton-anyag kölcsönhatásáról egy vastagabb anyag esetén [3]

Ez lehetővé teszi olyan megmunkálások létrejöttét, amelyek csak az átlátszó anyag belsejében történik meg.

\section{A mikromegmunkálások lehetséges technikái lézersugaras technológia esetén}

A mikromegmunkálások esetén különböző geometriák fordulhatnak elö. Lehetnek egyenes vagy görbe csatornák különbözö keresztmetszet alakokkal, mélységekkel és szelességekkel. Továbbá lehetnek kör vagy adott formájú területek különböző mélységig kimunkálva az alapanyagból.

\subsection{Mikromegmunkálás spirál geometriával}

A kör alapterületű kimunkálásokat a különböző spirálok egyesítésével sikerült a legpontosabban és legszebben elérni a PMMA megmunkálása során. Ezt a technikát a következő ábra mutatja be (5. ábra).

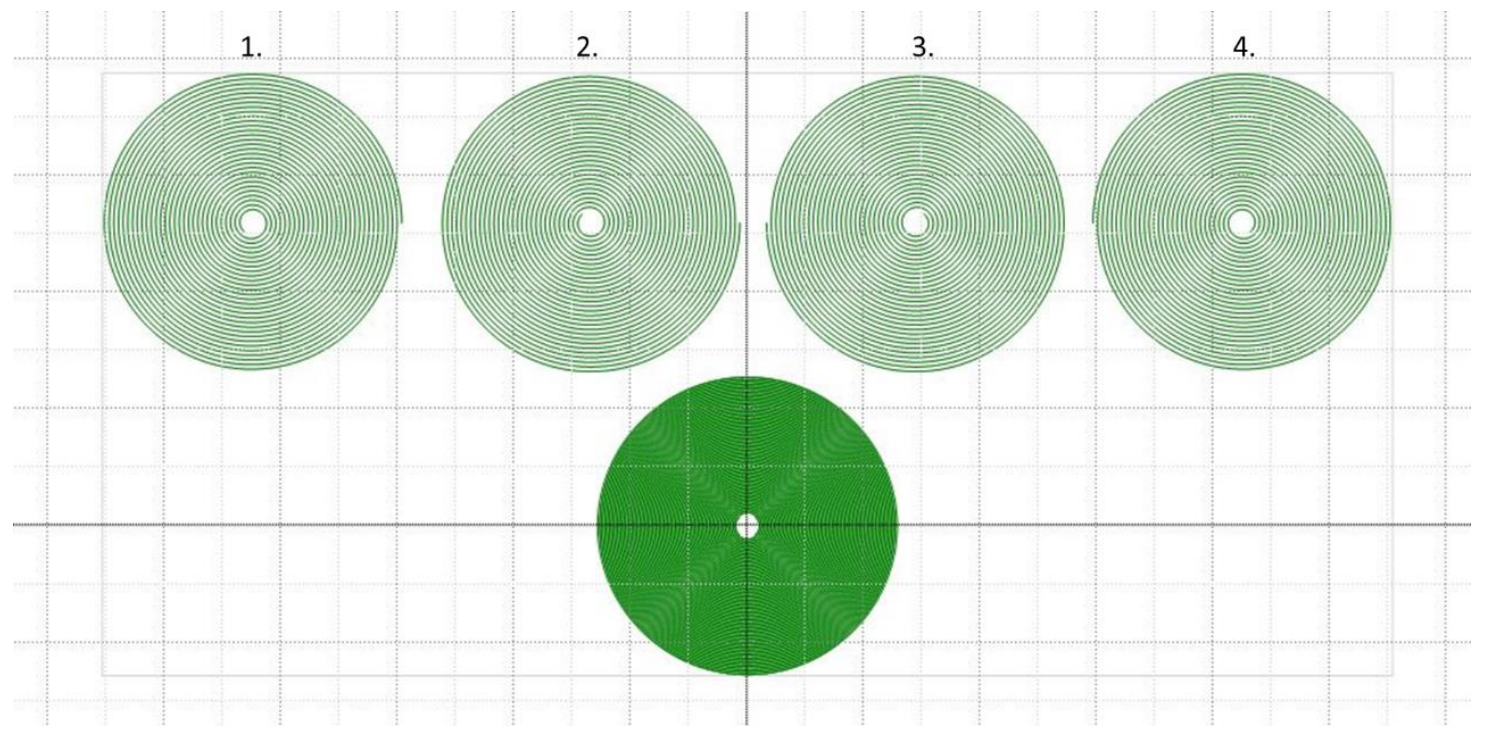

5. ábra. Kör alapterület kimunkálásának technikája 
Az 5. ábra alapján látható, hogy egy ilyen alapterület kimunkálása több spirál geometriából tevődik össze. Az első spirál esetében a lézersugár bentröl halad a geometria külseje felé az óra mutató járásával megegyező irányban, majd a második spirállal folytatva ugyanazon irányban halad tovább a lézersugár, csak a geometria szélétöl pásztázik a közepéig. A harmadik spirál megmunkálása során szintén az óramutató járásával megegyező irányba halad a sugár a geometria közepétöl a széléig, a negyedik spirál esetén a szélétől a közepéig.

Ezzel a technikával egyenes falú, akármilyen mély anyageltávolítás lehetséges. Fontos, hogy a spirálok között a fókusztávolságot mindig után kell állítani, vagy nem lesz egyenes falú a kimunkált mélyedés. Ezt meg lehet tenni dinamikus fókuszállítással.

\subsection{Mikromegmunkálás wobbling technika segítségével}

A lézersugaras megmunkálások esetén a lézersugár foltátmérője adja azt, hogy milyen széles csatornát munkálunk ki az anyagból. A csatornák szélességének szabályozására két lehetőség van lézersugaras megmunkálás esetén. Az egyik a defókusz alkalmazása, a másik a wobbling technológia. A defókusz alkalmazásával az a probléma, hogy a foltméret növelésével csökkentjük a teljesítménysürüséget, így nem feltétlen teljesítjük az ablációhoz szükséges energiasürüséget. Ennek az a következménye, hogy az anyag csak melegedik, olvadék keletkezik, ami pontatlanabb megmunkáláshoz vezet.

Ezzel szemben a wobbling technológia fókuszban történik és a sugár különleges mozgatásával lehet elérni a szélesebb csatorna létrejöttét. A technikát a következő ábra szemlélteti (6. ábra).

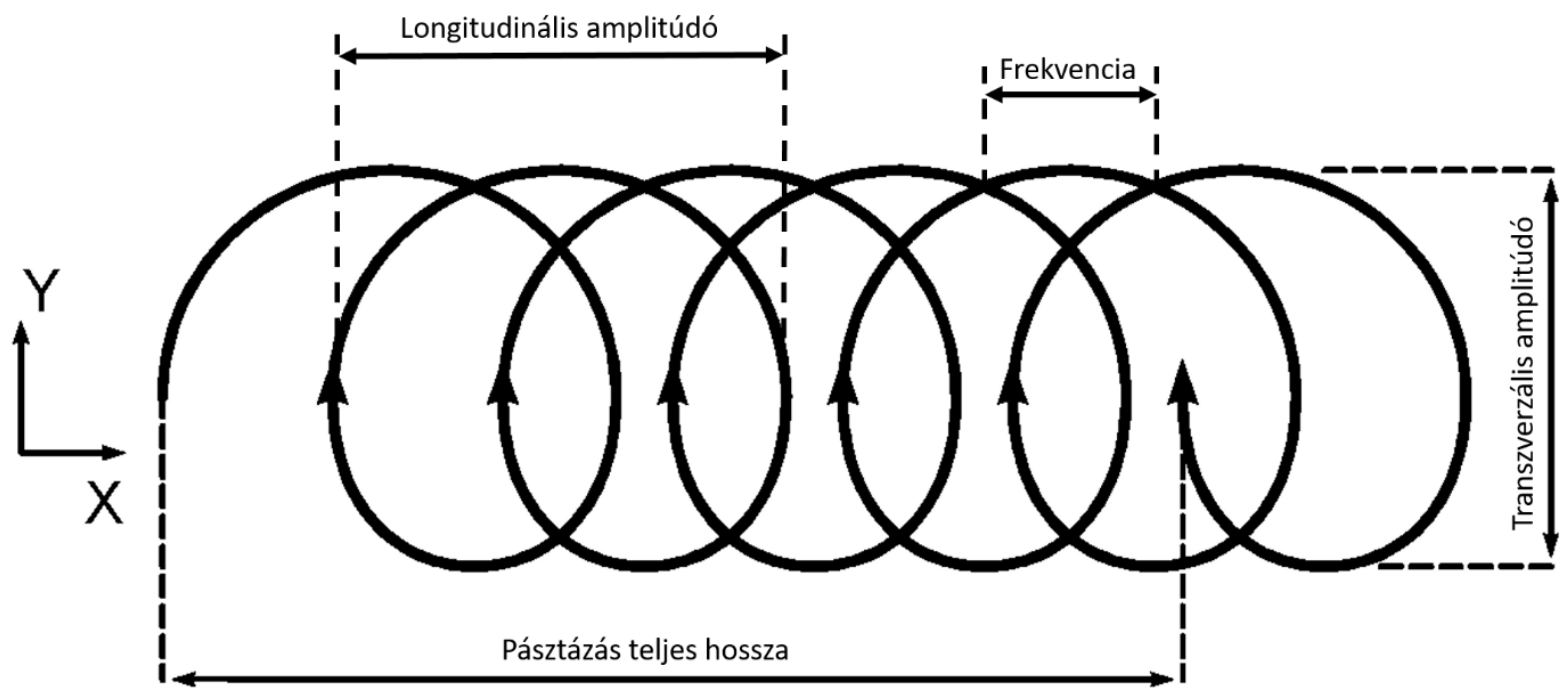

\section{6. ábra. Sematikus ábra a wobbling technikáról}

Az ábráról leolvashatók a wobbling technika állítható paraméterei. A longitudinális amplitúdóval a hurok hossza, a transzverzális amplitúdóval a hurok szélessége állítható. A frekvenciával az irányítható, hogy milyen gyakori legyen a hurok ismétlődése. Ezzel a technikával széles trapéz keresztmetszetű csatornákat lehet kimunkálni a munkadarabból megfelelő paraméterek alkalmazása mellett.

\section{Mikromegmunkálási példa femtoszekundumos lézerrel}

Egy Coherent Monaco femtoszekundumos lézerberendezéssel történtek alapkísérletek átlátszó PPMA műanyagon. Az előbbiekben említett technikák alkalmazásával és a megfelelő paraméterek beállításával különböző geometriák mikromegmunkálása történt meg a mủanyagon. $A$ geometriák a következők: egyszerü egyenes vonal, szélesített egyenes vonal és kör alapterületü mélyítés. A geometriák mélysége változó volt. A kör alapterületű mélyítések aljának érdessége 
további pásztázással mérsékelve lett. A cél az volt, hogy a geometriák teljes mértékben irányítottá váljanak, mind keresztmetszet alak, mind mélység szempontjából. A mintázatot a következő ábra mutatja be (7. ábra).

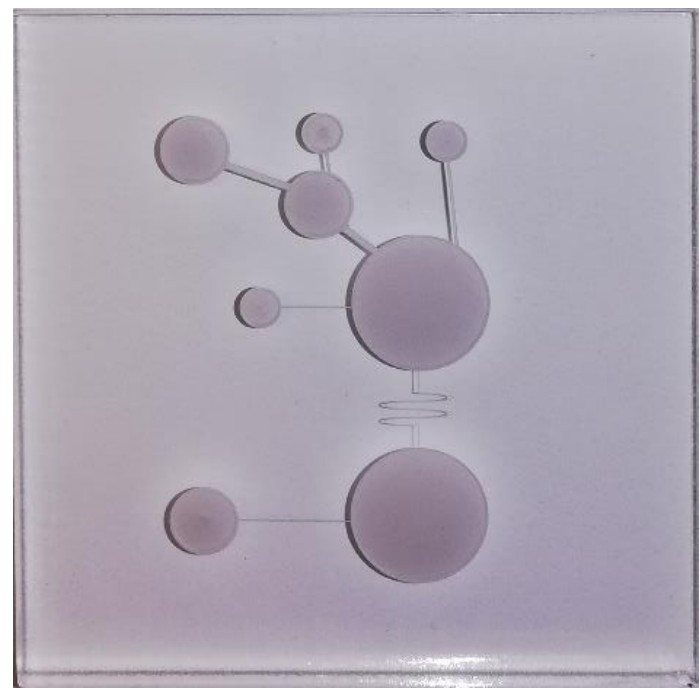

7. ábra. PMMA müanyag mikromegmunkálása femtoszekundumos lézerrel

A nagyobb nagyítású mikroszkópi felvételeken látható, hogy a megmunkálás széle éles, de minimális olvadás tapasztalható (8. ábra).

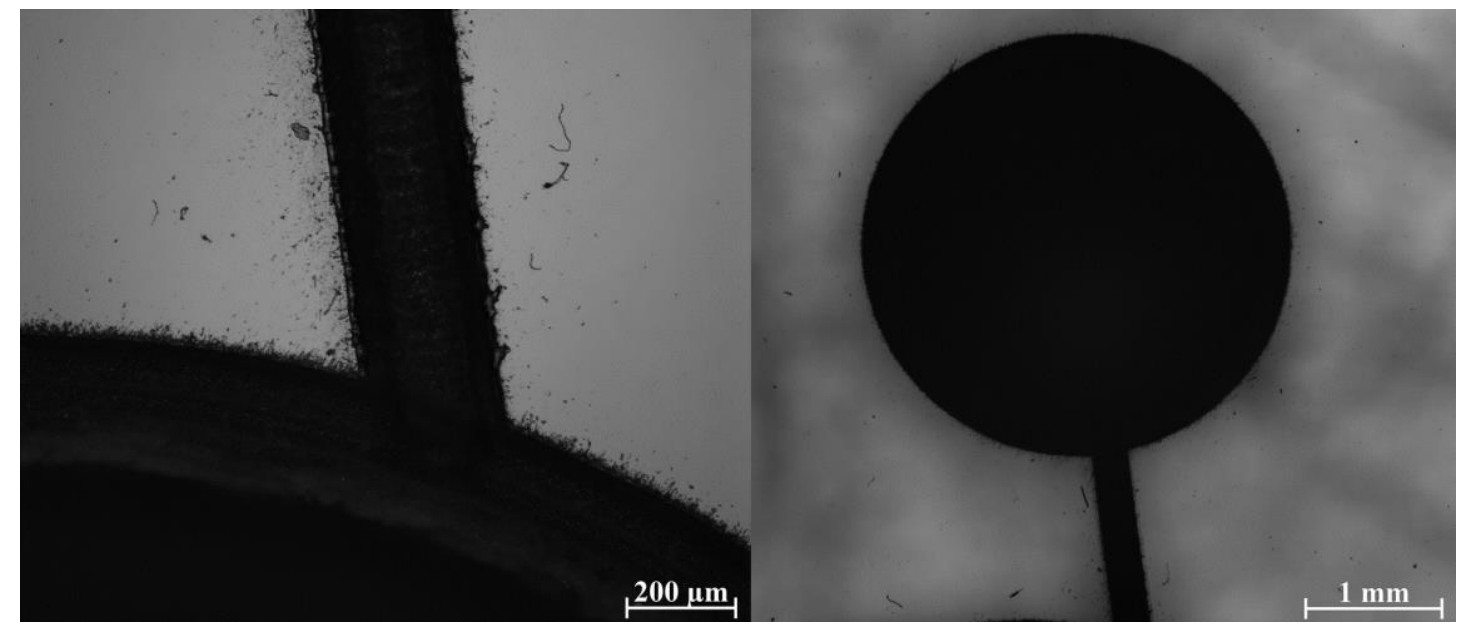

8. ábra. Mikroszkópi felvételek a mikromegmunkálásokról

A kör alapterületü mélyítések alján a spirál technikával nagyon érdes felület keletkezett. Ezért további lézersugaras pásztázást kellett alkalmazni, amelynek végeredményét a 9 . ábra mutatja be. 


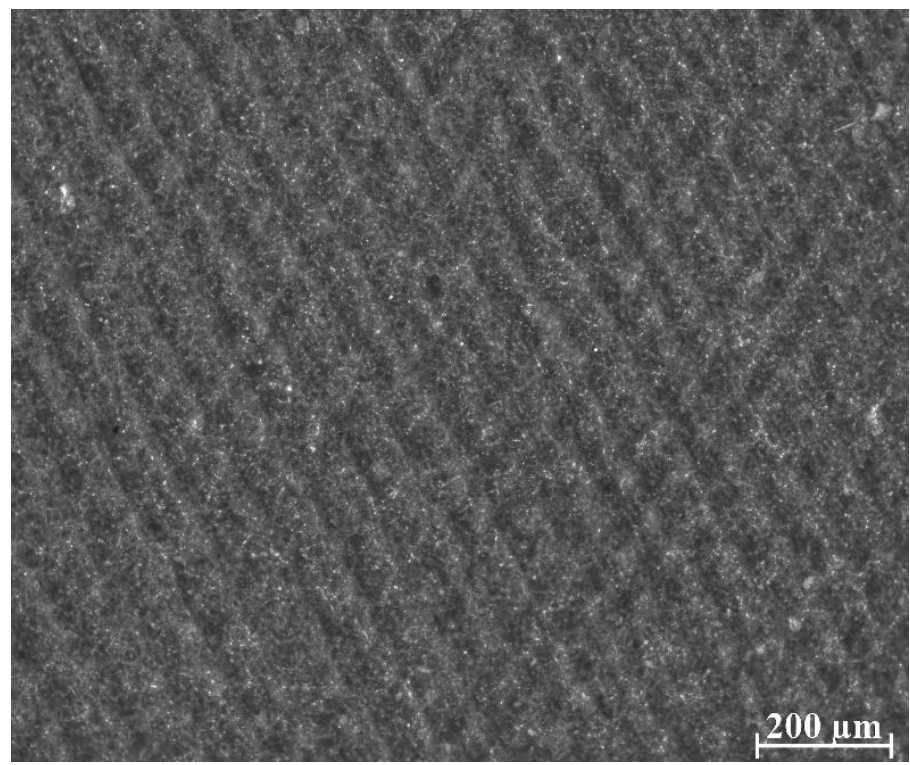

9. ábra. Az érdességcsökkentés végeredménye

A kimunkált geometriák keresztmetszete irányíthatóak ezekkel a technikákkal, viszont a megmunkálások további optimalizálása szükséges a minimális visszaolvadás megszüntetése érdekében.

\section{Köszönetnyilvánítás}

Köszönettel tartozunk a kutatás támogatásáért, amely az EFOP-3.6.1-16-2016-00014 pályázat keretében valósult meg. A projekt a Magyar Állam és az Európai Unió támogatásával valósult meg.

\section{Irodalomjegyzék}

[1] Viboon Tangwarodomnukun, Seksit Mekloy, Chaiya Dumkum, Asa Prateepasen, Laser micromachining of silicon in air and ice layer, Journal of Manufacturing Processes, Volume 36, 2018, Pages 197-208, ISSN 1526-6125, https://doi.org/10.1016/j.jmapro.2018.10.008

[2] "This One-Cent Lab-on-a-Chip Can Diagnose Cancer and Infections " Elérhetőség: https://singularityhub.com/2017/02/19/one-cent-lab-on-a-chip-can-detect-cancer-and-infections/ Megtekintve: 2020.09.26.

[3] Koji Cheng, Ya, Ultrafast Laser Processing From Micro- to Nanoscale, CRC Press, (2013)

[4] Marcos Dantus, Femtosecond Laser Shaping From Laboratory to Industry, CRC Press (2017)

[5] Lei Li, Cheng Wang, Yong Nie, Bo Yao, Huan Hu, Nanofabrication enabled lab-on-a-chip technology for the manipulation and detection of bacteria, TrAC Trends in Analytical Chemistry, Volume 127, 2020, 115905, ISSN 0165-9936 